\title{
Information on sister journals
}

\section{ILO Bulletin of Labour Statistics}

The Bulletin of Labour Statistics is published quarterly, with Supplements in the intervening months. It presents monthly and quarterly series on employment, unemployment, hours of work, wages and consumer prices from national official statistics.

A separate edition of the Bulletin is published towards the end of each year with the results of the ILO October Inquiry, an annual survey of wages and hours of work in 159 occupations and of retail prices for 93 food items.

The regular quarterly issues of the Bulletin usually include one or more articles of methodological interest in the area of labour statistics.

Recent articles published in the Bulletin of Labour Statistics

1991-1

Collecting traditional labour force data through modern techniques - The case of the Swiss Labour Force Survey (B. Buhmann and R. Hussmanns)

1991-2

La mesure du niveau d'instruction de la population active dans les Enquêtes auprès de la main-d'oeuvre (M. Imbert)

1991-3

i) The unemployed in administrative statistics and in the labour force survey in Finland (A. Laihonen)

ii) Registered unemployed and labour force survey unemployed: Comments and Danish experiences (V.L. Nielsen)

1991-4

ILO-comparable employent and unemployment estimates: updated results and methodology (I. Chernyshev and S. Lawrence)

The majority of articles is written in English with a short summary in French and Spanish.

Editor: Ms. Hazel Bennett, Bureau of Statistics, ILO, 4 route des Morillons, CH-1211 Geneva 22, Switzerland. 


\section{The Review of Income and Wealth}

Journal of the International Association for Research in Income and Wealth Income and Wealth Series 36

\section{CONTENTS}

March, 1990

Comparisons of Purchasing Power, Real Output and Labour Productivity in Manufacturing in Japan, South Korea, and the USA, 1975-1985

Adam Szirmai and Dirk Pilat

Accounting for Time Use

Graham Pyatt

Trends in Poverty in the United States, 1967-1984

McKinley L. Blackburn

Can a Perpetual Inventory Capital Stock be Used for Production Function Parameter Estimation?

Edward M. Miller

Service Industries in the Business Sector of the Canadian Economy Kishori Lal

The Measurement of Capital Through a Fixed Asset Accounting Simulation Model (FAASM)

Michael Jaffey

June, 1990

The Intergenerational Correlation between Children's Adult Earnings and their Parents' Income: Results from the Michigan Panel Survey of Income Dynamics

Jere R. Behrman and Paul Taubman

Measuring the Value of Household Output: A Comparison of Direct and Indirect Approaches

John Fitzgerald and John Wicks

Wealth Holdings and Poverty Status in the U.S. Edward N. Wolff

Conceptual Considerations on Satellite Systems D. Schafer and C. Stahmer

The Contracting-Out Problem in Service Analysis: Choice of Statistical Unit Harry Postner

The Dutch Economy, 1921-1939: Revised Macro-Economic Data for the Interwar Period Gert P. den Bakker, Theo A. Huitker, and Cornelis A. van Bochove 
A Balance of Payments Analysis of the Latin American Debt Crisis

J. Thomas Romans and Stanton A. Warren

Financial Consistency in Longitudinal Microsimulation: Homemaker Pensions Reexamined

Bruce Kennedy

September, 1990

The Economic Well-Being of the Elderly

Stephen Crystal and Dennis Shea

The Welfare State and Poverty in Finland and Sweden from the mid-1960s to the mid-1980s Bjorn Gustafsson and Hannu Uusitalo

Netting Out Income Taxes for Different Types of Income of Households Utz Reich and Klaus Schuler

Units in National Accounts and the Basic System of Economic Statistics Adriann M. Bloem

Stock Flow Consistent Income for Industrial and Commercial Companies K.D. Patterson

A Note on the Concept of Services

Laszlo Drechsler

December, 1990

Economic Burdens of Marital Disruptions: A Comparison of the United States and the Federal Republic and Germany

Richard V. Burkhauser, Greg J. Duncan, Richard Hauser, and Roland Berntsen

Major Changes Proposed for the Next SNA: An Overview Anne Harrison

The Impact of Bequests on Lifetime Wealth Accumulation: An Econometric Study of Two Generations of Rural Households in India

Anil B. Deolalikar and R.P. Singh

Gender Wage Differences in Australia, Sweden, and the United States Shelley A. Phipps

Aspects of Poverty In Greece

Panos Tsakloglou

On International Trade in Banking Services Thomas K. Rymes

A Note on the Revision of the United Nations System of National Accounts

Richard Ruggles 